\title{
Crowdsourcing of COVID-19 symptoms map in Ecuadorians
}

\author{
Siuling Ching-Ávalos ${ }^{1}$, Yadira Jaramillo-Lindao ${ }^{1}$, Andrés Velastegui-Montoya, $\mathrm{PhD}^{1,2}$, Luis Encalada, $\mathrm{PhD}(\mathrm{c})^{3,4}$, \\ Roberto Chang-Silva, BsC ${ }^{1}$, Mayte Mosquera-Romero, Dra ${ }^{5}$ \\ ${ }^{1}$ Escuela Superior Politécnica del Litoral (ESPOL), Ecuador, sching@espol.edu.ec, yalijara@espol.edu.ec, dvelaste@espol.edu.ec, \\ rojachan@espol.edu.ec \\ ${ }^{2}$ Federal University of Pará (UFPA), Geoscience Institute, Brazil \\ ${ }^{3}$ Universidade de Lisboa (U Lisboa), Portugal, luisencalada@campus.ul.pt \\ ${ }^{4}$ Universidad Espíritu Santo, Samborondón, Ecuador. \\ ${ }^{5}$ Universidad de Antioquia (UdeA), Colombia, maytemosquera90@gmail.com
}

\begin{abstract}
The COVID-19 pandemic significantly affected the city of Guayaquil. The complex dynamics associated with the geography of SARS-CoV-2 made it difficult to monitore the spread of COVID-19 in Ecuador. Data collection and reporting were, in most cases, some of the main obstacles to understanding the (realtime) situation of COVID-19 outbreak. This study presents a crowdsourcing initiative to complement data collection efforts that inform the progress of contagion in Ecuador. We used a digital survey to collect information regarding positive cases and symptoms associated with COVID-19. We further developed an online dashboard that shows descriptive statistics based on collected data. In total, there were 1450 responses. Additional information such as geographical data led to the identification and visualization of the areas with the highest prevalence of symptoms associated with COVID-19 in some of the main urban areas of Guayaquil city.

Keywords-- Covid-19 symptoms, data collection, crowdsourcing, coronavirus, covid-19, GIS.
\end{abstract}

\section{INTRODUCTION}

On February 11, 2020, the World Health Organization (WHO) identified new cases of "viral pneumonia" reported from December 31, 2019, by the Wuhan Municipal Health Commission, China as "SARS-CoV-2" [1]. Subsequently, it was identified that people who contracted the new virus presented symptoms such as fatigue, fever, dry cough, loss of the senses of taste and smell, among others, at variable intensity $[2,3]$. The rapid spread and mortality of the virus in several countries forced the WHO to declare a state of emergency due to the COVID-19 pandemic, posing larger challenges to public health and the global economy $[4,5]$.

Eventually, the arrival of the new coronavirus in Latin American countries demanded public health policies, to mitigate its rapid transmission among the population. In Ecuador, as of March 17, 2020, Presidential Decree No. 1017 was issued, as a control strategy in the face of the rapidly increase of infections [6]. A state of exception was declared, applying social isolation policies and mobility limitations. Despite the restrictions, the country witnessed a bewildering number of COVID-19 infections. In April 2020, Ecuador ranked first in deaths per capita in South America [7]. At the

Digital Object Identifier (DOI):

http://dx.doi.org/10.18687/LACCEI2021.1.1.124

ISBN: 978-958-52071-8-9 ISSN: 2414-6390 beginning of May, in Guayas, more than $60 \%$ of the cases were found within Ecuadorian territory [8]. Parallel to the adoption of contagion prevention strategies, there was a need for health agencies and governments to constantly spread true, updated, and scientifically based information that would lead to a change in the attitude of citizens [9].

In this context, a crowdsourcing initiative was developed for the mapping of symptoms associated with COVID19 cases. Crowdsourcing refers to a process of taking advantage of technology, by a group of people in open cooperation, to solve problems [10]. In times of pandemic, crowdsourcing represents an alternative to strengthen epidemiological surveillance in the collection of information associated with symptoms and characteristics of those infected [11]. On the other hand, the comprehensive analysis of the data within the geographic information systems contributes to the identification of spatial patterns "cluster" for monitoring the behavior of the disease [12].

The symptom mapping proposal is based on the importance of assessing the spread of COVID-19 in Ecuador. The purpose of the project is to offer the global community an open and permanent access source of the spatial distributions of the progression of symptoms associated with COVID-19 and positive cases of SARS-CoV-2. As a result, a map of prediction of areas with greater vulnerability to contagion due to the incidence of cases was generated. In total, 1,450 people participated, of which 655 reported some symptom associated with COVID-19, located mainly in the city of Guayaquil and other locations on the Ecuadorian coast.

\section{METHODOLOGY}

Initially, a bibliographic review was carried out on the symptoms presented in patients with COVID-19, which made it possible to structure a form in the ArcGIS Survey123 application [13], to collect georeferenced data from a mobile or a PC with an internet connection. Before the beginning of the survey, participants were asked to accept their voluntary, and free participation, in addition to the commitment of confidentiality and responsibility to enter truthful information.

The form included 19 questions, that addressed 3 main blocks of research interest. The first block corresponds to demographic data, such as age, gender, and geolocation. The second block is related to the symptomatic picture presented 
(fever, dry cough, body fatigue, partial or total loss of smell or taste, among others), which can identify individuals suspected of the disease and report if they have evidence of COVID- 19 and its respective result. It was also consulted for the presence of comorbidities (diabetes, hypertension, lung problems, among others) and the search for medical attention during the disease process. The final block investigated the possible exposure to the virus of each participant, mainly associated with the type of work carried out during the quarantine period.

\section{Localización*}

Por favor, haga click en el mapa y permita el acceso de localización de su dispositivo móvil o navegador web para poder indicar su posición.

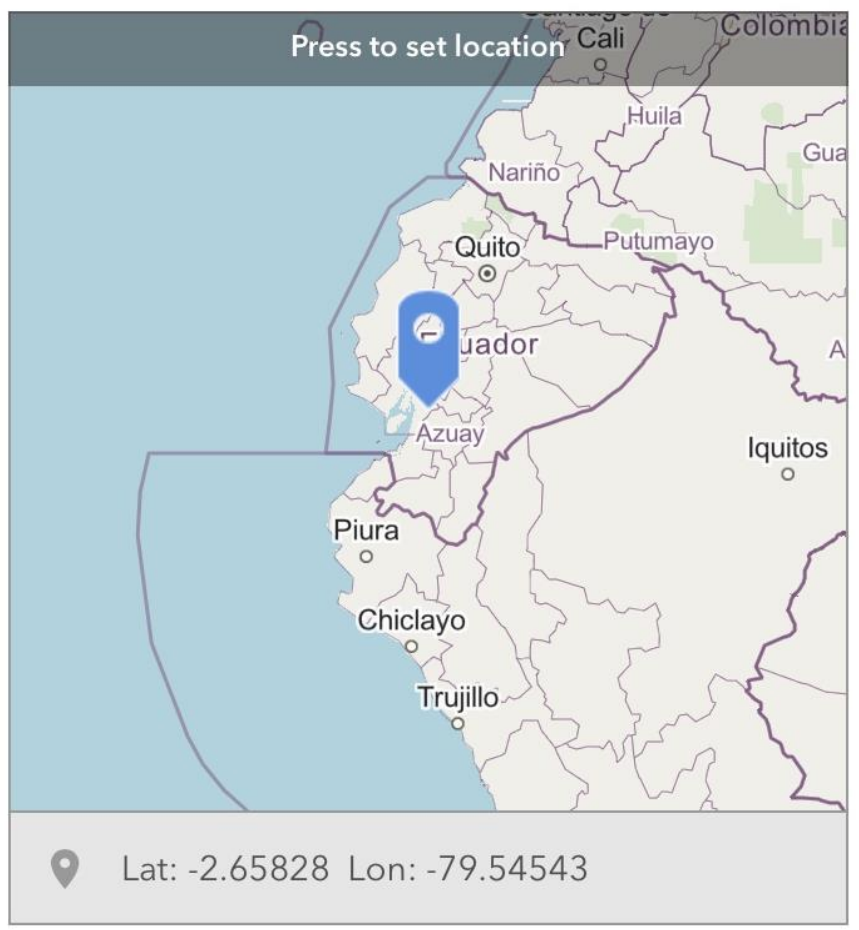

Fig. 1 Geolocation section

Survey 123 allows the collaborator to provide their location by clicking the map shown in Fig. 1, which will place the pin on the corresponding geographic coordinates. The person can also search for an address to use. In addition, access to the location is done only once to create a map of symptoms associated with COVID-19.

The remote diagnosis section of the form, observed in Fig. 2 , enabled the submission of a physical symptomatic record. By default, the absence of symptoms was considered. Moreover, if a person doubted having signs of the disease, the option called "not sure" was available.

\section{TELEDIAGNÓSTICO}

Sintomas

Indique la presencia (SI) o ausencia (NO) de los

siguientes síntomas. En caso de no estar seguro/a

marque la casilla correspondiente.

\begin{tabular}{|c|c|c|c|}
\hline & $\mathrm{SI}$ & NO & $\begin{array}{l}\text { NO ESTÁ } \\
\text { SEGURO/A }\end{array}$ \\
\hline Fiebre* & & () & \\
\hline Tos seca* & & & \\
\hline $\begin{array}{l}\text { Fatiga } \\
\text { corporal* }\end{array}$ & & & \\
\hline $\begin{array}{l}\text { Pérdida } \\
\text { parcial o } \\
\text { total del } \\
\text { olfato* }\end{array}$ & & & \\
\hline $\begin{array}{l}\text { Pérdida } \\
\text { parcial o } \\
\text { total del } \\
\text { gusto* }\end{array}$ & & & \\
\hline Flema* & & & \\
\hline $\begin{array}{l}\text { Dificultad } \\
\text { para } \\
\text { respirar* }\end{array}$ & & & \\
\hline $\begin{array}{l}\text { Dolor de } \\
\text { cabeza* }\end{array}$ & & & \\
\hline $\begin{array}{l}\text { Dolor de } \\
\text { garganta* }\end{array}$ & & & \\
\hline $\begin{array}{l}\text { Congesti } \\
\text { ón nasal* }\end{array}$ & & & \\
\hline Vómito* & & & \\
\hline Diarrea* & & & \\
\hline
\end{tabular}

Fig. 2 Remote diagnosis section

As the risk of having dangerous symptoms of COVID-19 can increase in people with serious health problems, the form had the block shown in Fig. 3 for categorization by risk groups, which also considered the lack of such affections by default. 


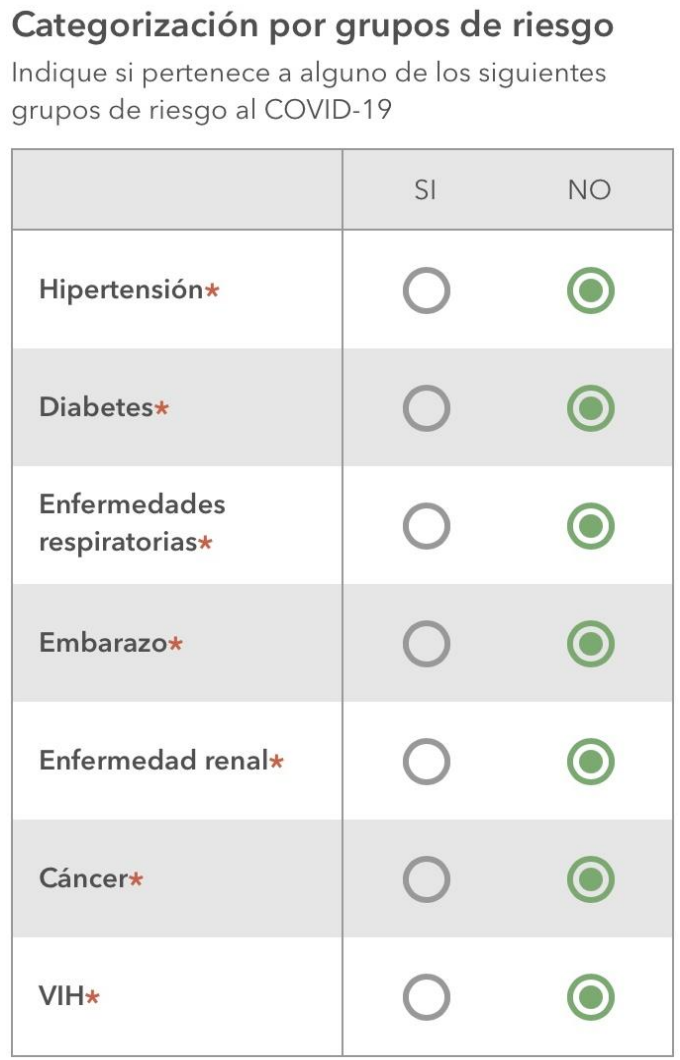

Fig. 3 Categorization by risk groups section

An open collaboration strategy (crowdsourcing) was used to guarantee inclusion and citizen participation, as the main source of data, which allowed the direct collection of information, in real-time. To motivate community participation, campaigns were carried out by the Faculty of Engineering in Earth Sciences (FICT) of the Escuela Superior Politécnica del Litoral (ESPOL) to disseminate the digital form on the social networks Twitter [14] and Facebook [15].
It is important to highlight that, for the development of the digital form, the participants only required a mobile or fixed device, with internet service.

As a strategy to encourage citizen participation, the data collected was published in real-time in an interactive viewer of geographic data through the ArcGIS Dashboard application [16], which allows viewing and filtering the data previously collected, in addition to browsing freely on the map, without being a GISexpert (Geographic Information System). The Dashboard (Fig. 4) presented the maps of participants who had at least one symptom associated with coronavirus, people who tested positive for COVID-19, and people who belong to at least one risk group. To guarantee the anonymity and safety of the community, the location approximation of the georeferenced data was limited, so that the maps do not reveal the exact position of the participants. Subsequently, the ArcGIS Experience Builder tool [17] was used to condense the desktop and smartphone versions of the project Dashboard into a single web access [18].

Finally, the data collected was processed in the ArcGIS Pro program [19]. The Summarize Within tool was used to superimpose and associate the symptomatologic data with the layer of neighborhoods and sectors of Greater Guayaquil. Next, a spatially restricted multivariate clustering was performed, with five previously specified clusters.

\section{RESULTS AND DISCUSSION}

With the multivariate clustering process, the data was grouped into five sets of different territorial extensions, made up of contiguous neighborhoods given the applied spatial restrictions. The smallest group corresponds to the sector with private urbanizations located east of the Vía Salitre (Fig. 5). This demarcation has the lowest incidence of symptoms because only 3 participants from the sector declared not having manifested any of the symptoms.

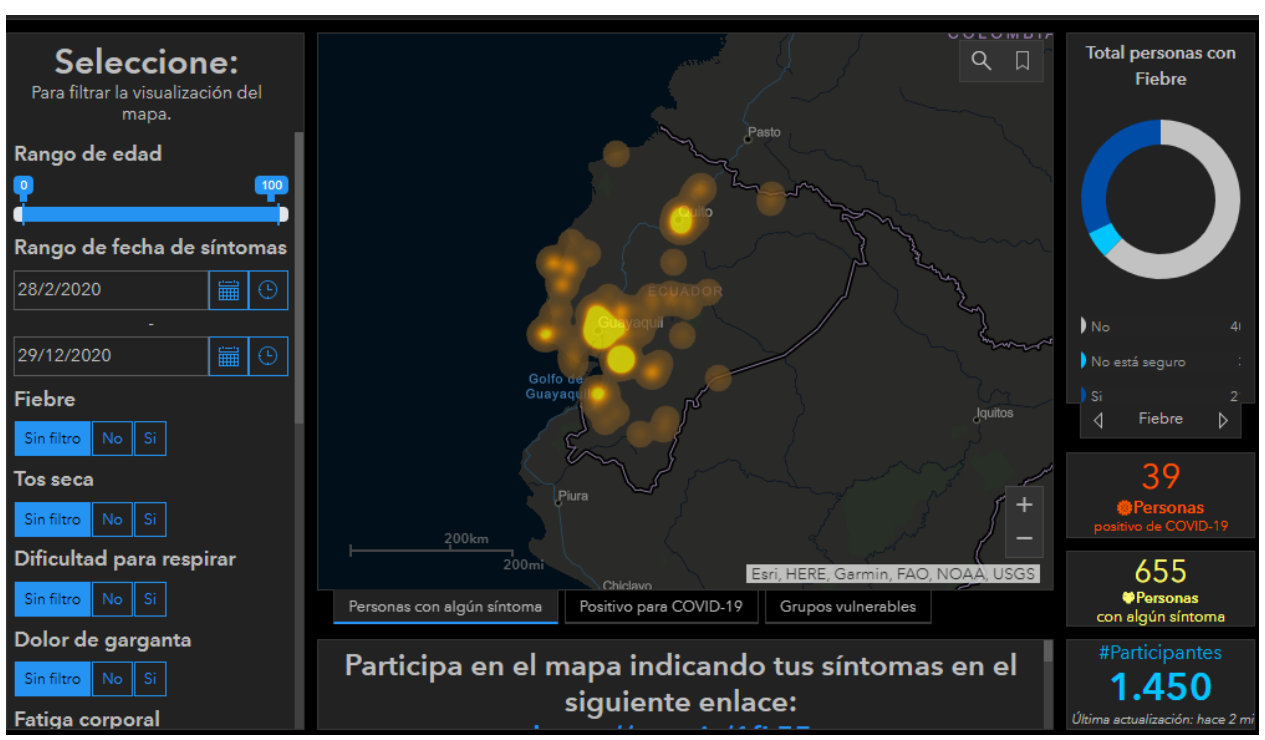

Fig. 4 COVID-19 symptom mapping dashboard in Ecuadorians 

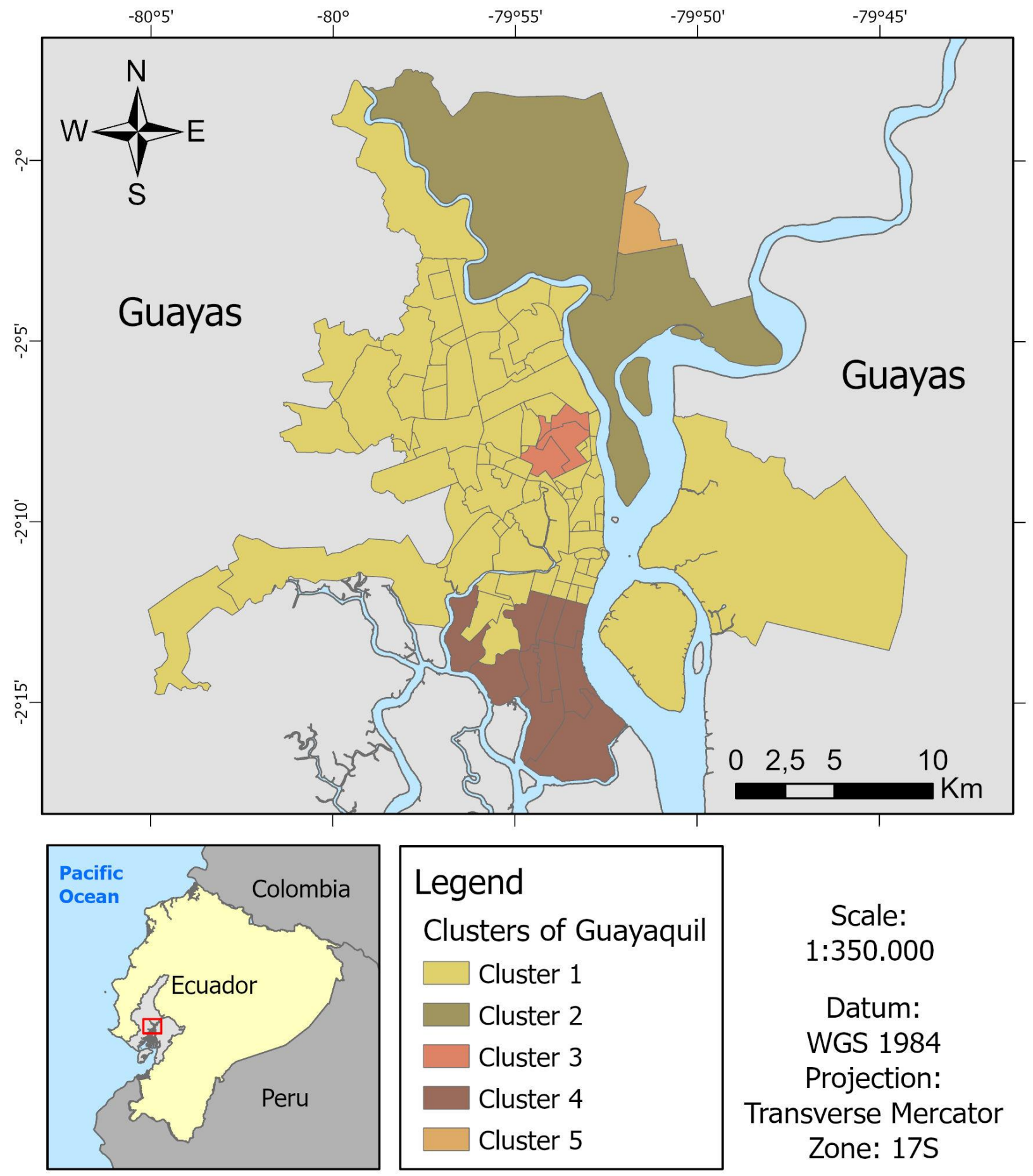

Fig. 5 Map of clusters of symptomatic conditions associated with COVID-19, in the neighborhoods and sectors of Greater Guayaquil.

On the other hand, the largest group covers 76 of the 90 neighborhoods and sectors considered in this study. The records of symptoms associated with COVID-19 in this area were below the average value, that is, a large part of the participating population did not report discomfort during the execution of the project. It should be noted that several neighborhoods did not have participants in the form, however, the spatial proximity allowed the inclusion of these neighborhoods in cluster 1. (Fig. 5).

Cluster 4 corresponds to Isla Trinitaria and Batallón del Suburbio, areas that have a multidimensional poverty rate greater than $50 \%$ [20]. In the same cluster, we have the 
neighborhoods and sectors of Guasmo, Fertisa, Letamendi, García Moreno, Ayacucho, La Pradera, and Los Esteros, all located south of the city of Guayaquil. The standardized symptom values are close to the average value, with a high percentage of symptomatic symptoms reported, concerning the number of study participants within this cluster. Coincidentally, in part of the neighborhoods included in cluster 4, incidents of non-compliance with the mobility restrictions contemplated in the state of exception in Ecuador were reported [21].

The La Alborada, Los Sauces, and Guayacanes neighborhoods are within cluster 3 . The standardized values of symptoms are above the mean, based on the number of participants. Finally, the urban parishes of La Aurora and La Puntilla are grouped in cluster 2. These urban parishes of middle and high economic strata, respectively, presented the highest incidence of symptoms associated with COVID-19.

During the project activity period, few positive COVID19 cases were recorded. Most of the participants who reported their symptoms confirmed that they did not carry out the COVID-19 tests for either economic reasons, low availability of centers to carry out the test, and/or for fear of contagion. In this context, this initiative made it possible to monitor in realtime the spread of symptomatic conditions associated with COVID-19 in Greater Guayaquil.

Despite the positive aspects of this work, it is important to recognize the limitations it had. In the beginning, there was great participation of the citizens, however, it declined over time. The peaks of participation coincided with the first hours of diffusion made by the official accounts of the FICT, which are aimed at a small audience, mainly university students. For these projects, constant and massive dissemination is vital. The project served as a direct and real-time communication medium for the community that reported their symptoms, as a parallel mechanism to the official media.

In the context of the pandemic, a multidisciplinary approach is important, including the areas of public health, citizenship, and governance. Crowdsourcing and GIS applied in the health area are a great opportunity to integrate, standardize and organize the entire process related to data collection and responsible decision-making, which allows defining preventive strategies and implementing policies in Public Health. However, these technologies by themselves do not guarantee success for those who were created, it's success will depend on the ability of decision-makers to interpret the information, and counteract the problem by relying on the tools presented in this work.

\section{CONCLUSION}

Crowdsourcing for mapping symptoms associated with COVID-19 pictures is a voluntary geographic information system for real-time and proactive feedback on the advance of the coronavirus. The study provides an open access for participants, citizens, and decision-makers, through an interactive Dashboard. These initiatives can improve the response capacity of public health systems, by monitoring in real-time the progress of symptomatic conditions associated with COVID-19 in the population. They also allow to monitor and understand the effectiveness of preventive measures implemented by local governments, such as social distancing and mobility restrictions.

\section{REFERENCES}

[1] M World Health Organization, "Naming the coronavirus disease (COVID-19) and the virus that causes it," https://www.who.int/emergencies/diseases/novel-coronavirus2019/technical-guidance/naming-the-coronavirus-disease-(covid-2019)and-the-virus-that-causes-it, Accessed: 2020-12-16.

[2] T.T. Nguyen et al., "Health Literacy and Preventive Behaviors Modify the Association between Pre-Existing Health Conditions and Suspected COVID-19 Symptoms: A Multi-Institutional Survey," Int. J. Environ. Res. Public Health, vol. 17, no. 22, p. 8598, Nov. 2020.

[3] World Health Organization, "Preguntas y respuestas sobre la enfermedad por coronavirus (COVID-19)," https://www.who.int/es/emergencies/diseases/novel-coronavirus2019/advice-for-public/q-a-coronaviruses, Accessed: 2020-12-16.

[4] World Health Organization, "Archived: WHO Timeline - COVID-19," https://www.who.int/news-room/detail/27-04-2020-who-timeline---covid19, Accessed: 2020-12-16.

[5] L. Akin and M.G. Gözel, "Understanding dynamics of pandemics," Turkish J. Med. Sci., vol. 50, no. 1, pp. 515-519, 2020.

[6] Ministerio de Defensa Nacional, "El presidente Lenín Moreno decreta estado de excepción en Ecuador," https://www.defensa.gob.ec/elpresidente-lenin-moreno-decreta-estado-de-excepcion-en-ecuador/, Accessed: 2020-12-15.

[7] A. Millán, "Coronavirus: ¿por qué Ecuador tiene el mayor número de contagios y muertos per cápita de covid-19 en Sudamérica?," https://www.bbc.com/mundo/noticias-america-latina-52036460, Accessed: 2020-12-16.

[8] El Comercio, "Guayas cierra abril del 2020 con más muertes que en 4 meses del 2019; el contexto del covid-19 en Ecuador," https://www.elcomercio.com/actualidad/record-muertes-guayascoronavirus-ecuador.html, Accessed: 2020-12-16.

[9] The Lancet, "COVID-19: the medium is the message.," https://www.thelancet.com/article/S0140-6736(20)30600-0/fulltext, Accessed: 2020-12-20.

[10]C. Nguyen, N. Tahmasbi, T. de Vreede, G.J. de Vreede, O. Oh, and R. Reiter-Palmon, "A Definition of Community Crowdsourcing Engagement and Application," in Blurring the Boundaries Through Digital Innovation. Lecture Notes in Information Systems and Organisation, vol. 19, pp. $283-$ 296. 2016.

[11]K. Wazny, "Applications of crowdsourcing in health: An overview," $J$. Glob. Health, vol. 8, no. 1, p. 010502, 2018.

[12]C. Zhou et al., "COVID-19: Challenges to GIS with Big Data," Geogr. Sustain., vol. 1, no. 1, pp. 77-87, 2020.

[13]Environmental Systems Research Institute, "ArcGIS Survey123." https://survey123.arcgis.com/, Accessed: 2020-12-20.

[14]FICT ESPOL (@FictESPOL), “Los invitamos a participar y a difundir el mapeo en tiempo real de síntomas asociados al brote \#COVID2019Ec entre ecuatorianos y extranjeros residentes, una iniciativa de @espol y @ULisboa_ \#SomosESPOL [Tweet]," Twitter, 2020. https://twitter.com/FictESPOL/status/1251159430122463238\%3E.

[15]ESPOL (@espol), "Los invitamos a participar y a difundir el mapeo en tiempo real de síntomas asociados al brote \#COVID2019Ec entre ecuatorianos y extranjeros residentes, una iniciativa de ESPOL y Universidade de Lisboa. \#SomosESPOL," Facebook, 2020. https://www.facebook.com/espol/posts/10158061814278286.

[16]Environmental Systems Research Institute, "ArcGIS Dashboards." https://www.esri.com/en-us/arcgis/products/arcgis-dashboards/overview, Accessed: 2020-12-20.

[17]Environmental Systems Research Institute, "ArcGIS Experience Builder." https://experience.arcgis.com/page/landing, Accessed: 2020-12-20. 
[18]Escuela Superior Politécnica del Litoral and Universidade de Lisboa, "Mapeo Geosintomático COVID-19 en ecuatorianos," https://experience.arcgis.com/experience/ddea9909d2f2433f8f52d7f85a04 6e72/, Accessed: 2021-01-12.

[19]Environmental Systems Research Institute, "ArcGIS Pro." https://www.esri.com/en-us/arcgis/products/arcgis-pro/overview, Accessed: 2020-12-20.
[20]A. Molina-Vera, "Desarrollo Sostenible al interior de la ciudad de Guayaquil 2010: Territorializando la Agenda 2030," Boletín de Política Económica, Guayaquil, pp. 13-19, Sep. 2018.

[21]K. Pesantes, "Guayas: medidas extremas ante una situación descontrolada," https://www.primicias.ec/noticias/sociedad/coronavirusguayas-medidas-extremas-descontrol/, Accessed: 2021-01-12 